\title{
Free and Open Indo-Pacific Strategy Outlook
}

By David Arase

\section{EXECUTIVE SUMMARY}

- The United States launched a new Free and Open Indo-Pacific (FOIP) strategy in late 2017 after reluctantly concluding that its patient effort to engage and socialize China to the rules-based order since 1972 had failed. China's behaviour since 2009 convinced the United States that China is a revisionist power seeking to impose an authoritarian model of governance in Asia which, if successful, would end the rules-based order in the Indo-Pacific as well as endanger US security and vital trade interests.

- The new US FOIP strategy initiative seeks to engage like-minded nations in economic, security (both traditional and non-traditional), and political governance partnerships to construct a collaborative and scalable network of relations that will be able to respond flexibly to meet a wide range of stakeholder needs and regional contingencies across the Indo-Pacific region.

- The United States occupies a peak organizing role in this network and works with a hierarchy of partners distributed throughout the vast Indo-Pacific to meet the economic, security, and governance capacity needs of network members at any level. The rules-based order is the "operating system" of this network approach, and so the network itself sustains the rules-based order for its members as a collective good. FOIP is more like a club that generates rules-based order benefits for its members and as such has little in common with Cold War bloc politics and containment strategy.

- Bearing in mind that FOIP is only in its start-up phase and is likely to gather momentum going forward; that the elements of this network strategy are already in place; and that the United States and its main FOIP partners together have considerable material, organizational, and soft power resources, one may say that its prospects for long-term sustainability and success are not bad. 
